\title{
EVALUASI PENERAPAN PERLAKUAN AKUNTANSI TERHADAP AKTIVA TETAP BERDASARKAN PSAK NO 16 PADA PT. PEGADAIAN ( PERSERO ) CABANG MALALAYANG MANADO
}

\author{
Muhammad Bahari Hariadi ${ }^{1}$, Grace B Nangoi ${ }^{2}$, Anneke Wangkar ${ }^{3}$ \\ 1,2,3 Jurusan Akuntansi, Fakultas Ekonomi dan Bisnis, Universitas Sam Ratulangi, Jl. Kampus Bahu, Manado, \\ 95115, Indonesia \\ E-mail : Muhammadaeyi@gmail.com
}

\begin{abstract}
Company is organization that has certain activities to achieve the objectives charged to him. Each company has a goal to be achieved, both short-term and long-term, that is to gain profit and increase the company's profit. A goal will be achieved if a company is well managed and supported by means that can help achieve the goal. One of the supporting facilities used to achieve these objectives is fixed assets. Fixed Asset is a very important company asset, without a fixed asset it is impossible for a company to use its regular operational activities properly according to the Indonesian Accounting Association (2015: 16), Fixed assets are tangible properties held for use in the production or supply of goods or services to other parties or for administrative purposes and is expected to be used for more than one period. Fixed assets are company assets whose period of use is more than one accounting normal period (usually one year of use). Property assets belonging to fixed assets, ie land, buildings, machinery (mechines), vehicles, copyrights and so on. The Company's fixed assets are obtained through various means, among other things, by cash purchase, credit purchase, purchase with securities, exchange, obtained from prizes or donations and built on their own. Because of its long age, the assets are still needed as an investment so that the company is able to manage effectively and efficiently. as time goes by, the benefits of fixed assets will generally decrease continuously, leading to depreciation. All fixed assets may experience depreciation except land. Depreciation calculations are usually based on management policy in accordance with commonly used methods. Based on the description above, very interested to discuss more deeply about fixed assets. This prompted the authors for the final compilers entitled "Evaluation Of Accounting Treatment On Earning Asset Based On Financial Accounting Standard Number 16 At PT Pegadaian (Persero).
\end{abstract}

\section{PENDAHULUAN}

Dalam penelitian Ernawati (2015) menemukan bahwa kebijakan penyusutan yang dilakukan oleh PT Pelayaran Liba Marindo Tanjungpinang belum sesuai dengan ketentuan yang terdapat dalam PSAK No.16. Dimana perhitungan penyusutannya tidak menggunakan salah satu metode penyusutan yang terdapat dalam PSAK No.16, Perusahaan menerapkan kebijkan penyusutan yang ditentukan dari manajemen perusahaan.

Aset tetap tidak selamanya terus diguanakan perusahaan karena ada aset yang mempunya masa manfaat terbatas akan berhenti beroperasi. Penghentian ini termasuk dalam perlakuan pelepasan aset tetap. Pelepasan aset tetap dapat dilakukan dengan cara dibuang, dijual atau ditukar. Aset yang dilepaskan perusahaan harus melalui pertimbanganpertimbangan yang sesuai agar tidak lagi terdaftar dalam akun aset tetap. Begitupun aset tetap yang sudah habis nilai buku, dijual atau ditukarkan dengan aset tetap lainnya agar aset tetap yang terdaftar sama jumlahnya dengan aset tetap yang beroperasi. 
Pihak manajemen PT. Hasjrat Multifinace Manado tidak pernah melakukan penghentian aset tetap dan ini terlihat dari aset tetap yang umur ekonomisnya telah habis (nilai perolehan telah habis disusutkan), dan sudah tidak dapat digunakan lagi, tetapi masih ada didalam daftar aktiva tetap perusahaan dimana belum sesuai dengan PSAK No.16 (Budiman,2014).

Menurut penulis yang telah ditulis di PT Pegadaian Persero mengenai dimana penghentian dan pelepasan aset tetap perusahaan belum sesuai dengan PSAK No.16 karena menurut PSAK No.16 jumlah tercatat aset tetap dihentikan pengakuannya pada saat dilepas atau ketika tidak terdapat lagi manfaat ekonomi masa depan yang diharapkan dari penggunakan atau pelepasan sedangkan perusahaan masih mengakui nilai tercatat sebesar harga perolehan kedalam perkiraan aset tetap didalam laporan keuangan perusahaan (Yuliyanti,2014)

Pengungkapan aset tetap pada penyajian laporan keuangan harus dijelaskan seara rinci. Ketidaklengkapan pengungkapan laporan membuat pemakai atau pengguna kebingunan. Pemakai akan menilai perusahaan bersuaha menutupi informasi yang sebenarnya dan kualitas lapornan keuangan mnjadi tidak akurat. Untuk itu prnyajian dan pengungkapan aset tetap harus berpedoman pada Standar Akuntansi Keuangan.

\section{TINJAUAN PUSTAKA}

\subsection{PSAK No 16 (Revisi 2015)}

PSAK No. 16 atau Pernyataan Standar Akuntansi Keuangan No. 16 adalah tentang aset tetap. Dimana Pernyataan Standar Akuntansi Keuangan 16 (revisi 2015): Aset Tetap terdiri dari paragraph $01-83$. Seluruh paragraph dalam PSAK ini memiliki kekuatan mengatur yang sama.Tujuan dalam pernyataan ini bertujuan untuk mengatur perlakuan akuntansi aset tetap, agar pengguna laporan keuangan dapat memahami informasi mengenai investasi entitas untu aset tetap, dan perubahan dalam investasi tersebut. Isu utama dalam akuntansi aset tetap adalah pengakuan aset, penentuan jumlah tercatat, pembebanan penyusutan, dan rugi penurunan nilai atas aset tetap. Ruang lingkup PSAK No. 16 diterapkan dalam akuntansi aset tetap kecuali peryataan lain mensyaratkan atau mengizinkan perlakuan akuntansi yang berbeda. Pernyataan ini tidak diterapkan untuk:

1. Aset tetap diklasifikasikan sebagai dimiliki unutk dijual sesuai dengan PSAK 58 (revisi 2009): Aset tidak lancar yang dimiliki untuk dijual dan Operasi yang Dihentikan ;

2. Pengakuan dan pengukuran aset eksplorasi dan evaluasi (PSAK 64) : Aktivitas Eksplorasi dan Evaluasi pada Pertambangan Sumber Daya Mineral;

3. Hak penambangan dan cadangan mineral dari minyak, gas dalam dan sumber daya tidak terbarui lainya.

\subsection{Aset Tetap}

Aset tetap berwujud atau sering disebut fixed asset merupakan harta kekayaan yang berwujud, relative permanen, dan digunakan dalam operasi regular lebih dari satu tahun. Aset tetap berwujud dibeli dengan tujuan untuk tidak dijual kembali. Aset tetap berwujud terdiri dari atas tanah, bangunan atau gedung, mesin-mesin. Perabot dan peralatan kantor. Aset tetap berwujud yang umurnya tidak terbatas misalnya tanah, disajikan berdasarkan harga perolehan dikurnagi dengan akumulasi ini disebut nilai buku atau aset tetap berwujud bersih (Wahyudiono, 2014: 25).

Aset tetap merupakan aset perusahaan yang sangat penting, tanpa adanya aset tetap, mustahil sebuah perusahaan dapat menjalankan kegiatan operasionalnya dengan baik. Setiap perusahaan, baik yang bergerak dalam bidang jasa, perdagangan, maupun industry pasti memiliki aset tetap untuk menjalankan kegiatan operasional perusahaan setiap harinya. Adanya suatu aset tetap dalam perusahaan bukan hanya sekedar merasakan manfaatnya saja, 
tetapi bagaimana perusahaan mengontrol dan mengawasi setiap pengeluaran dan biaya aset tetap mulai dari pengadaan aset tetap, pemakaian aset tetap, hingga habis masa manfaatnya. Ini bertujuan agar perusahaan dapat mengetahui dengan pasti keadaan, kinerja dan nilai dari setiap aset tetap guna kelancaran kegiatan operasional perusahaan ( Balak, 2016).

\subsection{Konsep Akuntansi Keuangan}

Akuntansi keuangan adalah bagian dari akuntansi yang berkaitan dengan penyiapan laporan keuangan untuk pihak luar, seperti pemegang saham, kreditor, pemasok, serta pemerintah. Prinsip utama yang dipakai dalam akuntansi keuangan persamaan akuntansi (asset $=$ liabilitas + ekuitas). Akuntansi keuangan berhubungan dengan masalah pencatatan transaksi untuk suatu perusahaan atau organisasi dan penyusunan berbagai laporan berkala dari hasil pencatatan

\subsection{Klasifikasi Aset Tetap}

Setiap perusahaan memiliki jenis aset tetap yang berbeda karena kegiatan operasional yang dilakukan perusahaan juga berbeda-beda.

1. Dari sudut pandang substansinya aset tetap terdiri dari :

1) Aset berwujud (tangible Assets) seperti lahan, gudung, mesin dan lain-lain.

2) Aset tidak berwujud (itangible Assets) yaitu aset yang secara fisik dapat dinyatakan seperti hak cipta, dan lain-lain.

In the developed markets, the economic value of a company reflects, for a large part, its intangible assets. In front of this type of assets which is in continuous growth, the traditional accounting system carry out more and more difficulty to insure their informative role in the decisions-making process. Pernyataan tersebut menjelaskan bahwa dipasar negara maju, nilali ekonomi suatu perusahaan untuk sebagaian besar dicerminkan oleh aset tidak berwujudnya. Didepan jenis aset yang dalam pertumbuhan yang berkelanjutan, sistem akuntansi tradisional melaksanakan lebih dan lebih sulit untuk memastikan peran informative mereka dalam proses pengambilan keputusan (Brahim, 2012).

2. Dari sudut pandang penyusutan aset tetap terdiri dari :

1) Depreciated plant Assets (Aset tetap yang disusutkan) yaitu aset tetap yang umur masa penggunaannya terbatas dan dapat diganti dengan yang sejenis apabila masa penggunaanya telah berahir.

2) Undeperciated plant Assets (Aset tetap yang tidak disusutkan) yaitu aset tetap yang umur masa penggunaannya tidak terbatas.

\subsection{Perolehan Aktiva Tetap} berikut :

Aktiva tetap dapat diperoleh melalui beberapa cara. Diantaranya adalah sebagai

1. Pembelian tunai

Harga perolehan aktiva tetap yang dibeli dengan tunai meliputi semua pengeluranan dan pembayaran yang terjadi untuk mendapatkan aktiva tetap tersebut sampai pada kondisi siap pakai untuk digunakan. Pembelian aktiva tetap secara tunai dicatat sebesar uang yang dikeluarkan untuk pembelian tersebut termasuk biaya pengangkutan, biaya pemasangan aktiva tetap dan biaya-biaya lain.

2. Pembelian secara kredit

Pembelian secara kredit mengakibatkan adanya penangguan pembayaran. Hutang biasanya dibuktikan dengan wesel, surat berharga, hutang hipotok. Hutang ini dibayar dengan beberapa kali angsuran di tambah dengan pembayaran bunganya. Hal ini berarti pembelian secara kredit membutuhkan pembayaran lebih besar dari pada membeli tunai.

3. Pembelian dengan surat berharga 
Aktiva tetap yang diperoleh dengan mengeluarkan surat-surat barharga berupa saham atau obligasi dicatat sebesar harga pasar atau obligasi pada saat perolehan aktiva tersebut. Selisih antar harga pasar saham/obligasi tersebut. Jika surat berharaga dan aktiva tetap tidak memiliki nilai pasar, maka perolehan dapat diterapkan oleh pimpinan perusahaan atau dewan komisaris.

4. Diterima dari sumbangan

Perusahaan dapat memperoleh aktiva tetap dari sumbagan atau bantuan pemerinatah atau badan-badan lain. Transaksi ini disebut dengan "nonrespirocal transfer" atau transfer yang tidak mengeluarkan umpan balik. Aktiva ini harus dicatat sebesar seharga pasar yang wajar atau berdasarkan penialaian yang dilakukan oleh pihak atau perusahaan penilai independen dan kredit sebagai modal donasi.

5. Dibanguan sendiri

Tedapat beberapa factor yang memengaruhi perusahaan dalam memenuhi kebutuhan aktiva tetap dengan membangunnya sendiri, antara lain:

a. Menekan biaya

b. Kegiatan untuk mendapatkan mutu yang lebih baik

c. Memanfaatkan fasilitas yang menganggur

d. Aktiva tetap yang dibutuhhkan tidak dijual dipasaran

\subsection{Pengeluaran Setelah Pengakuan Awal Aktiva Tetap}

Selama aktiva tetap dipergunakan dalam operasi perusahaan biasanya timbul pengeluaran-pengeluaran yang berkaitan dengan aktiva tetap yang bersangkutan, miaalnya pengeluaran untuk reparasi, penambahan atau penggantian komponen aktiva yang bersangkutan. Pengeluaran semacam ini disebut pengeluaran setelah perolehan.

Menjelaskan bahwa Pernyataan Standar Akuntansi keuangan Nomor 16 (2009:16.7) pengeluaran setelah perolehan awal suatu aktiva tetap yang memperpanjang masa manfaat atau yang kemungkinan besar memberi manfaat keekonomian dimasa yang akan datang dalam bentuk peningkatan kapasitas, mutu produksi, atau peningkatan standar kinerja, harus ditambahkan pada jumlah tercatat aktiva yang bersangkutan.

Setelah aktiva diakui akan nada pengeluaran-pengeluaran untuk menunjang kinerja aktiva tetap. Pengeluaran-pengeluaran ini terjadi dua yaitu pengeluaran modal yang dikeluarkan dengan maksud menambah masa manfaat aktiva tetap, dan pengeluaran beban yang dikeluarkan untuk sekedar memelihara kinerja aktiva tetap.

\subsection{Penyusutan dan Metode Penyusutan Aktiva Tetap}

Manfaaat yang diestimasi, Menurut Standar Akuntansi Keuangan (2011:17.2) menjelaskan "adalah alokasi jumlah suatu aktiva yang dapat disusutkan sepanjang masa penyusutan.

Ikatan akuntansi Indonesia mengungkapkan bahwa metode penyusutan dapat dilakukan dengan berbagai metode yang dapat dikelompokkan menurut kritertia berikut:

a. metode garis lurus (straight line methtod).

Metode ini adalah depresiasi yang paling sederhana dan banyak digunakan. Dalam cara ini, beban depresiasi tiap periodenya jumlahnya sama. Besarnya depresiasi yang konstan setiap periode seolah-olah menunjukan bahwa kemampuan aktiva tetap relatif sama dalam suatu periode. Padahal kemampuan aktiva tetap semakin lama menurun dan karenanya kurang logis diterapkan.

$$
\text { Depresiasi }=(\mathrm{HP}-\mathrm{NS}) / \mathrm{n}
$$

Keterangan :

$$
\begin{array}{ll}
\mathrm{HP} & =\text { Harga Perolehan }(\cos t) \\
\mathrm{NS} & =\text { Nilai Sisa } \\
\mathrm{N} & =\text { Taksiran Umur Kegunaan }
\end{array}
$$

b. Metode saldo menurun (diminishing balance method). 
Metode jumlah menurun ini akan menghasilkan beban penyusutan yang menurun setiap periode. Metode ini beranggapan bahwa akiva baru sangat besar perannya dalam usaha mendapatkan penghasilan, peranan aktiva tersebut semakin lama semakin megecil seiring dengan semakin tuanya aktiva tersebut. Tarif pajak dalam metode ini ditentukan terlebih dahulu dan besarnya sama untuk setiap tahun. Penyusutan dihitung dengan mengalihkan tarif dengan nilai buku yang semakin kecil.

c. Metode jumlah unit (Sum of the unit method).

Dalam metode ini umur kegunaan/masa manfaat aktiva tetap ditafsirkan dalam satuan jumlah unit hasil produksi. Beban penyusutan dihitung dengan dasar satuan hasil produksi, sehingga penyusutan tiap periode akan berfluktuasi sesuai dengan fluktuasi dalan hasil produksi. Dasar teori yang dipakai adalah suatu aktiva itu dimiliki untuk menghasilkan produk, sehingga depresiasi juga didasarkan pada jumlah produk yang dapat dihasilkan. Umumnya jumlah hasil produk yang akan diproses bersifat estimasi sehingga tidak menutup kemungkinan dibelakang hari akan terjadi bahwa estimasi yang dibuat akan lebih rendah, lebi tinggi atau sama dengan kenyataan sesunguhnya.

Definisi diatas menjelaskan bahwa penyusutan adalah pengalokasian harga perolehan aktiva tetap menjadi beban kedalam periode akuntansi. Dan untuk mengukur beban penyusutan harus menggunkan metode penyusutan yang sesuai serta diterapkan secara konsisten.

\subsection{Penelitian Terdahulu}

1. Penelitian yang dilakukan Eleanor (2016) berdasarkan hasil PT. Nichindo Manado Suisan Menjalankan Kegiatan Akuntansinya Berpedoman Pada Kebijakan Akuntansi Perusahaan Yang Sudah Mengarah Pada Psak No.16 Tetapi Perusahaan Menyusutkan Aktiva Tetapnya Menggunakan Metode Saldo Menurun Dimana Hal Ini Belum Sesuai Dengan Standar Akuntansi Yang Berlaku.

2. Penelitian yang dilakukan Fitriah (2013) hasil penelitiannya menunjukkan Bahwa Pengakuan,Pengukuran Dan Pelaporan Aktiva Tetap Pada PT Hasjrat Abadi Secara Umum Telah Sesuai Dengan Pernyataan Standar Akuntansi Keuangan Nomor 16.

\section{METODE PENELITIAN}

\subsection{Jenis dan Sumber Data}

Jenis data yang digunakan adalah data Kualitatif adalah data yang berhubungan dengankategorisasi, karakteristik berwujud pernyataan atau berupa kata-kata. Data ini biasanya di dapat dari wawancara yang bersifat subjektif.Sumber data Data Sekunder adalah data yang diperoleh secara tidak langsung melalui media perantara (Melihat penelitian yang sudah pernah dilakukan sebelumnya), menggunakan metode tinjauan kepustakaan (library reserch) membaca buku-buku yang berkaitan dengan masalah yang ingin diteliti, dan dilihat dari mengakses website dan situs-situs yang di berkaitan.

\subsection{Metode Analisis Data}

Analisis data yang dilakukan dengan menggunakan metode deskriptif dimana penelitian dilakukan dengan cara mengumpulkan laporan keuangan periode 2013-2016, dan yang dikumpulkan serta memberi keterangan yang dihadapi.

\section{HASIL ANALISIS DAN PEMBAHASAN \\ 4.1. Hasil Analisis \\ Pengakuan Awal}

Beberapa cara dalam hal memperoleh aktiva tetap pada PT. Pegadaian Persero dan cara untuk memiliki perolehan aktiva tetapnya yaitu, pembelian secara tunai. Adapun ketentuannya sebagai berikut. 
1. Pembelian secara tunai

Cara perolehan ini pada umumnya menyangkut investasi bergerak pada perusahaan tersebut, sebelum diputuskan untuk membeli suatu aktiva tetap, terlebih dahulu dibuat perencanaan yang jelas dan sesuai dengan kebutuhan perusahaan tersebut. Dalam penyusunan perencanaan harus jelas dan sesuai dengan kebutuhan pabrik, artinya yang dibelanjakan harus berdasarkan perencanaan yang disetujui, apabila diharuskan emminta persetujuan ualng dan beberapa aktiva tetap dibeli secara bersamaan dan tiap-tiap aktiva tidak disebutkan harganya, maka total harga yang dibebankan harus dialokasikan ke masing-masing aktiva yang bersangkutan.

\section{Pengeluaran Setelah Perolehan Aktiva Tetap}

Pernyataan Standar Akuntansi Keuangan mengungkapkan bahwa, selama aktiva tetap dioperasikan, perusahaan tidak dapat menghindari pengeluaran-pengeluaran yang diakibatkan dari perubahan keadaan aktiva tetap selama digunakan, seperti biaya untuk pemeliharaan, biaya untuk perbaikan, biaya untuk penambahan dan penyempurnaan lainnya. Hal ini dilakukan agar aktiva tersebut tetap dapat memberikan manfaat, sehingga aktiva tetap tersebut dapat bertahan selama masa pemakaiannya sampai umur ekonomisnya habis.

\section{Penyajian dan Pengungkapan Aktiva Tetap dalam Laporan Keuangan}

Laporan keuangan memiliki tujuan untuk memberikan informasi yang akurat dan transparan kepada pemakai laporan, sehingga penyajian aktiva tetap harus mendeskripsikan keadaan aktiva tetap dan dapat di mengerti oleh pemakai laporan keuangan sehingga pengambilan keputusan bisa dilakukan secara tepat.

PT. Pegadaian Persero menggolongkan aktiva tetapnya berdasarkan presentase penyusutannya yang diatur dalam aturan perpajakan, yaitu golongan I, II dan III. Penyajiannya dalam neraca dengan mencatat masing-masing aktiva tetap sebesar harga perolehannya dikurangi akumulasi penyusutan. Akumulasi penyusutan aktiva tetap di sini disajikan sebagai perkiraan pengurang atas aktiva tetap, karena cara ini dimaksudkan agar pemakai laporan keuangan merasa praktis dan mudah untuk membacanya.

Aktiva tetap yang disajikan dalam laporan keuangan tidak menggambarkan seluruh informasi mengenai aktiva tetap yang ada pada perusahaan tersebut. Informasi yang disajikan hanya sebatas jenis aktiva tetap, harga perolehan dari aktiva tetap dan akumulasi penyusutannya. Informasi ini tidak disajikan secara mendetail mengenai masing-masing aktiva tetap.

\subsection{Pembahasan}

\section{Pengakuan}

Evaluasi perbandingan pengakuan Aset tetap pada PT. Pegadaian (Persero) cabang Malalayang

\begin{tabular}{|c|c|c|}
\hline PSAK No.16 & $\begin{array}{c}\text { PT. Pegadaian (Persero) Cabang } \\
\text { Malalayang }\end{array}$ & Keterangan \\
\hline $\begin{array}{ll}\text { a. } & \text { Kemungkinan besar } \\
\text { entitas akan memperoleh } \\
\text { manfaat ekonomis masa } \\
\text { depan dari aset tersebut }\end{array}$ & $\begin{array}{c}\text { Perusaan mengakui aset yang } \\
\text { dimiliki dengan ketentuan yang } \\
\text { diperoleh adalah aset yang memiliki } \\
\text { dan memberikan masa manfaat } \\
\text { ekonomis. }\end{array}$ & Sesuai \\
\hline
\end{tabular}

Dari perbandingan pengakuan aset tetap oleh PT. Pegadaian (Persero) dengan PSAK No.16 berdasarkan hasil penelitian, untuk perlakuan aset tetapnya diketahui bahwa pengakuan aset tetap terjadi jika kemungkinan aset tetap yang dimiliki memberikan manfaat ekonomi bagi pihak perusahaan dan biaya perolehan aset dapat diukur secara andal. Dengan memberikan manfaat ekonomi, aset tetap yang diperkirakan akan memberikan manfaat dan menunjang operasional perusahaan sehingga perusahaan bisa menjalankan kegiatan operasional perusahaan dalam melayani konsumen dari penggunaan aset perusahaan. 
Contohnya, Perusahaan membeli komputer pada tanggal 25 agustus 2015, maka pihak perusahaan mengakui aset tersebut pada saat itu terjadinya transaksi dan dicatat pada tanggal itu juga. Dalam hal ini pengakuan aset perusahaan telah sudah sesuai dengan panduan yang dimiliki oleh perusahaan dan tidak menyimpang dari PSAK No, 16.

\section{Pengeluaran Setelah Perolehan}

Evaluasi perbandingan pengeluaran atas aset tetap setelah perolehan pada PT. Pegadaian (Persedo) Cabang Malalayang.

\begin{tabular}{|c|c|c|}
\hline PSAK No.16 & $\begin{array}{c}\text { PT. Pegadaian ( Persero ) } \\
\text { Cabang Malalayang }\end{array}$ & Keterangan \\
\hline a. Pengeluaran Setelah & $\begin{array}{c}\text { Pengeluaran untuk pemeliharaan } \\
\text { dan perbaikan aset tetap yang }\end{array}$ & Sesuai \\
perolehan awal suatu aset & menambah masa manfaat, \\
tetap memperpanjang masa & kapasitas dan mutu pelayanan & \\
manfaat di masa yang akan & aset tetap yang bersangkutan & \\
datang dalam bentuk & untuk beberapa tahun pada & \\
peningkatan kapsitas, & prinsipnya harus & \\
peningkatan standar kinerja, & dikapitalisasikan dengan & \\
atau mutu produksi harus & mendebet perkiraan yang & \\
ditambahkan pada jumlah & bersangkutan. & \\
tercatat pada aset & \\
bersangkutan. & & \\
\hline
\end{tabular}

Dari perbandingan pengeluaran aset tetap PT. Pegadaian (Persero) cabang Malalayang dengan PSAK No 16 berdasarkan perbandingan di atas pengeluaran untuk pemeliharaan dan perbaikan aset tetap yang menambah masa manfaat, kapasitas dan mutu pelayanan aset tetap yang bersangkutan untuk beberapa tahun.

Untuk mendeskripsikan pencatatan pengeluaran dalam akun aset, dimisalkan bahwa penambahan 1 (satu) mesin dan menghabiskan biaya sebesar Rp.15.000.000 , ayat jurnal yang perlu dibuat untuk penambahan ini adalah :

$$
\begin{array}{rrr}
\text { Mesin } & & \text { Rp. } 15.000 .000 \\
\text { - Kas } & \text { Rp. } 15.000 .000
\end{array}
$$

Penambahan tersebut akan disusutkan selama sisa manfaat dari mesin tersebut, sedangkan pengeluaran lainnya pada biaya yang dikeluarkan oleh perusahaan dalam melakuakan pemeliharaan dan perbaikan untuk semua mesin setiap akhir tahunnya, dan untuk tahun 2016 sebesar Rp. 1.000.000 dengan jurnal :

Biaya pemeliharaan Mesin - Kas

$$
\text { Rp. } 1.000 .000
$$

Rp. 1.000 .000

pada pencatatan jurnal diatas, perusahaan mencatat pengeluaran tersebut sudah sesuai dengan PSAK No 16, karena perusahaan mencatat pengeluaran tersebut agar tidak menjadi kesalahan dalam menghitung pencatatan pertanggungjawaban laporan keuangan perusahaan.

\section{Penyajian dan Pengungkapan}

Evaluasi perhitungan penyajian dan pengugkapan aset tetap pada PT. Pegadaian (Persero) cabang malalayang

\begin{tabular}{|l|c|c|}
\hline \multicolumn{1}{|c|}{ PSAK No.16 } & \multicolumn{1}{c|}{$\begin{array}{c}\text { PT. Pegadaian ( Persero ) } \\
\text { Cabang Malalayang }\end{array}$} & Keterangan \\
\hline a. $\begin{array}{l}\text { Aset tetap disajikan dalam } \\
\text { neraca sebesar nilai } \\
\text { perolehan aset tersebut } \\
\text { dikurangi dengan } \\
\text { akumulasi penyusutan. }\end{array}$ & $\begin{array}{c}\text { Penyajian aset tetap dalam neraca } \\
\text { dinyatakan sebesar nilai buku, } \\
\text { yaitu harga perolehan dikurangi } \\
\text { akumulasi penyusutan aktiva tetap } \\
\text { disajikan sebagai perkiraan } \\
\text { pengurangan atas aset tetap. }\end{array}$ & \\
\hline
\end{tabular}




\begin{tabular}{|c|c|c|}
\hline PSAK No.16 & $\begin{array}{c}\text { PT. Pegadaian ( Persero ) } \\
\text { Cabang Malalayang }\end{array}$ & Keterangan \\
\hline $\begin{array}{l}\text { b. Setiap jenis aset tetap } \\
\text { seperti tanah, bangunan } \\
\text { inventaris kantor dan lain } \\
\text { sebagainya harus } \\
\text { dinyatakan dalam neraca } \\
\text { secara terpisah atau } \\
\text { terperinci dalam catatan } \\
\text { atas laporan keuangan. }\end{array}$ & $\begin{array}{l}\text { Di dalam penyajian ada beberapa } \\
\text { yang menyajikan secara terpisah } \\
\text { menurut jenis aset itu sendiri. }\end{array}$ & Sesuai \\
\hline \multicolumn{3}{|l|}{$\begin{array}{l}\text { Laporan keuangan juga } \\
\text { harus mengungkapkan : }\end{array}$} \\
\hline $\begin{array}{ll}\text { a. } & \text { Keberadaan dan } \\
\text { jumlah retriksi atas } \\
\text { hak milik, dan aset } \\
\text { tetap yang dijaminkan } \\
\text { untuk liabilitas } \\
\end{array}$ & $\begin{array}{l}\text { Perusahaan mengungkapkan } \\
\text { mengenai keberadaan dan jumlah } \\
\text { retriksi atau hak milik dan aset } \\
\text { tetap yang dijamiinkan }\end{array}$ & Sesuai \\
\hline $\begin{array}{ll}\text { b. } & \text { Jumlah pengeluaran } \\
\text { yang diakui dalam } \\
\text { jumlah tercatat aset } \\
\text { tetap yang sedang } \\
\text { dalam pembangunan } \\
\end{array}$ & $\begin{array}{c}\text { Dalam penelitian ini penulis } \\
\text { hanya membahas soal aset tetap } \\
\text { perusahaan }\end{array}$ & Tidak sesuai \\
\hline
\end{tabular}

Berdasarkan pernyataan di atas terlihat perusahaan menyajikan aset tetap sebesar nilai buku, yaitu harga perolehan dikurangi akumulasi penyusutan aset tetap disajikan sebagai perkiraan pengurangan atas aset tetap disajikan dalam neraca sebesar nilai perolehan aset tetap dikurangi dengan akumulasi penyusutan.

Setiap jenis aset tetap harus dinyatakan dalam neraca secara terpisah atau diperinci pada catatan atas laporan keuangan, pada perusahaan sudah menerapkan kebijakan ini dan tidak menyimpang dari PSAK No.16.

Pengukapan aset tetap diharuskan untuk mengungkapkan dasar penilaian yang digunakan untuk menentukan jumlah terrcatat bruto. Jika lebih dari satu dasar digunakan jumlah tecatat bruto untuk dasar setiap kategori harus diungkapkan, dan pihak perusahaan telah menerapkan standar akuntansi keuangan.

\section{KESIMPULAN DAN SARAN}

\subsection{Kesimpulan}

Dari hasil penelitian dan pembahasan mengenai penerapan akuntansi aset tetap pada PT. Pegadaian (Persero) Cabang Malalayang, maka penulis menarik kesimpulan sebagai berikut :

1. PT. Pegadaian (Persero) Cabang Malalayang merupakan perusahaan yang bergerak di bidang jasa keuangan yang bertujuan untuk membantu mengatasi kesulitan masyarakat yang membutuhkan dana (uang), agar tidak jatuh ke parah pelepasan uang atau rentenir. Perusahaan Pegadaian menyediakan pinjaman uang dengan jaminan barang berharga. Prosedurunya mudah dan cepat, dan biaya yang di bebankan lebih ringan.

2. PT. Pegadaian (Persero) Menurut Pengertian Aset Tetap adalah aset berwujud dan tidak berwujud yang dimilik perusahaan untuk digunakan dalam produksi atau penyedian barang atau jasa, atau dalam operasional perusahaan atau untuk tujuan administratif tidak dimaksudkan untuk dijual dalam rangka kegiatan normal perusahaan dan tidak dibiayakan, serta memiliki masa manfaat lebih dari satu tahun. 
3. PT. Pegadaian (Persero) Cabang Malalayang metode garis lurus untuk mengalokasikan penyusutan aset tetapnya untuk setiap periode akuntansi dan menggunakan metode saldo berganda.

4. Penerapan aset tetap yang diterapkan oleh PT. Pegadaian No 16 Cabang malalayang, berpedoman pada standar akuntansi keuangan yang berlaku.

5. PT. Pegadaian (Persero) Cabang Malalayang tidak mempunyai pedoman akuntansi atas aset tetap tentang metode revaluasi, akan tetapi dalam PSAK No. 16 Metode revaluasi tersebut baru diberlakukan pada tahun 2015. Bagian akuntansi baru memberlakukan dalam pencatatan atas penelitian atas revaluasi aset tetap tersebut.

6. Seluruh aset tetap, pada akhir periode penyusutan akan disusutkan sekaligus sebesar nilai buku, kecuali jika aset tetap tersebut masih digunakan maka nilai bukunya ditetapkan Rp. 1,- dan untuk tahun berikutnya tidak dihitung beban penyusutan. Karena masih bisa digunakan aset tersebut dalam jangka waktu berlaku.

7. Jumlah pengeluaran yang diakui dalam jumlah tercatat aset tetap yang sedang dalam pembangunan, dalam penelitian ini penulis hanya membahas soal aset tetap perusahaan (Tidak Sesuai).

\subsection{Saran}

Menurut penulis akuntansi aset tetap pada PT. Pegadaian (Persero) Cabang malalayang sudah baik dan benar, karena telah mengacu kepada Standar Akuntansi Keuangan yang berlaku di Indonesia. Namun ada beberapa yang akan penulis sarankan kepada perusahaan terkait yaitu:

1. PT. Pegadaian (Persero) Cabang Malalayang seharusnya memiliki cabang residu terhadap aset tetapnya, agar perhitungan penyusutan lebih akurat.

2. Seharusnya PT. Pegadaian (Persero) Cabang Malalayang melakukan pembukuan revaluasi atas aset tetap karena revaluasi atas aset tetap baru diberlakukan pada PSAK No. 16 Tahun 2015.

\section{DAFTAR PUSTAKA}

Balak, Indra. 2016. Perlakuan Akuntasi Capital expenditure dan revenue expenditure pada PT. Maesa Nugraha Manado. Jurnal Emba Vol 4 Hal 19.

Brahim, Houneida. 2012. The relevance of the information about intangibles: some determinants. International journal of accounting and financial reporting Vol 2.

Budiman, Erwin. 2014. Analisis Perlakuan Akuntansi Aktiva Tetap Pada PT Hasrat Multifinace Manado 2012. Jurnal EMBA. Fakultas Ekonomi dan Bisnis Universitas Sam Ratulangi. Manado. Diakses tanggal 27 Maret 2016.

Eleanor, 2016. Evaluasi Penerapan Perlakuan Akuntansi terhadap Aktiva TetapBerdasarkan PSAK No.16 Tahun 2011padaPT. Nichindo Manado Suisan. Universitas Sam Ratulangi Manado. Fakultas Ekonomi dan Bisnis

Erlend Kvaal, 2005. Topics in Accounting for impairmen of fixed asset. Bi Noewegian school of management Departement of accounting, auditing and law.

Ernawati. 2015. Analisis Penerapan Standar Akuntansi Keuangan (PSAK No.16) Atas Aset Tetap Pada PT Pelayaran Liba Marindo Tanjungpinang. Tanggal Akses 27 Maret 2016. Jurnal UMRAH. Fakultas Ekonomi Universiatas Maritim Raja Ali Haji. TanjungPinang. Diakse tanggal 25 Maret 2016.

Erwin, 2014. Analisis Perlakuan Akuntansi Aktiva Tetap pada PT. Hasjrat MultifinanceManado. Universitas Sam Ratulangi Manado. Fakultas Ekonomi dan Bisnis.

Fatmawaty, 2016. Analisis Penerapan Akuntansi atas Aset Tetap pada PT. Sederhana Karya Jaya Manado. Universitas Sam Ratulangi Manado. Fakultas Ekonomi dan Bisnis. 
Fitrah, 2013. Analisis Pengakuan dan Pelaporan Aktiva Tetap Berdasarkan PSAK No.16. Universitas Sam Ratulangi Manado. Fakultas Ekonomi dan Bisnis.

Gaby, 2015. Analisis Sunk Cost atas Keputusan Penggantian Aset Tetap pada PT Pantai Timur Jaya. Universitas Sam Ratulangi Manado. Fakultas Ekonomi dan Bisnis.

Handre, 2016. Penerapan konsep Sunk Cost Terhadap Keputusan Pembelian Aktiva Tetap pada Ud. karena Bentenan.Universitas Sam Ratulangi Manado. Fakultas Ekonomi dan Bisnis

Hanne, 2013. Analisis Penerapan PSAK No.48 (Revisi 2009) Penurunan Nilai Aset Tetap pada Rumah Sakit Umum Pusat Prof.Dr.R.D. Kandow Manado. Universitas Sam Ratulangi Manado. Fakultas Ekonomi dan Bisnis

Ikbal, 2016. Analisis Penilaian Nilai Aset Tetap Bangunan Menurut PSAKNO.48 Tentang Penurunan Nilai Aset PT. Bank Rakyat Indonesia. Universitas Sam Ratulangi Manado. Fakultas Ekonomi dan Bisnis

Purba. 2013. Aset Tetap dan Aset Tak Berwujud. Graha Ilmu. Yogyakarta.

Yulianti, Erda. 2014. Perlakuan Akuntansi Aset Tetap Berdasarkan Psak No.16 Pada CV. Matalindo Jaya Bintan. Jurnal Umrah Fakultas Ekonomi, Universitas Maritim Raja Ali Haji. Kepulauan Riau. Diakses Tanggal 12 Maret 2016. 